\title{
Ferulic acid, gamma oryzanol and GABA content in whole grain rice and their variation with bran colour
}

\author{
Siaw Xiang Sing ${ }^{1,3}$, Huei Hong Lee ${ }^{1,3}$, Sie Chuong Wong ${ }^{1,3}$, Choon Fah Joseph Bong ${ }^{2}$, Pang Hung Yiu ${ }^{1,3 *}$ \\ ${ }^{1}$ Department of Basic Science and Engineering, Faculty of Agriculture and Food Sciences, Universiti Putra Malaysia, Nyabau Road, 97000 \\ Bintulu, Malaysia; ${ }^{2}$ Department of Crop Science, Faculty of Agriculture and Food Sciences, Universiti Putra Malaysia, Nyabau Road, 97000 \\ Bintulu, Malaysia; ${ }^{3}$ Centre of Excellence in Borneo Ecosystem Science Research, Faculty of Agriculture and Food Sciences, Universiti Putra \\ Malaysia, Nyabau Road, 97000 Bintulu, Malaysia
}

\section{A B S T R A C T}

\begin{abstract}
The health advantages of whole grain rice are largely associated with the bioactive food components namely, ferulic acid (FA), gamma oryzanol (GO) and gamma aminobutyric acid (GABA) in the germ and bran of grain kernel. This study was aimed to determine the content of these health-promoting compounds among 53 local rice cultivars and their relation to bran colours. There was remarkable amount of health-promoting compounds in the rice collection, especially "Segerit", "Merah" from Rumah Ulat and "Keladi" from Menitam. FA was the highest with an average of $1034.0 \mu \mathrm{g} / \mathrm{g}$ followed by GO $757.90 \mu \mathrm{g} / \mathrm{g}$ and GABA $191.16 \mu \mathrm{g} / \mathrm{g}$. Rice with pigmented bran stored more FA and GO than their non-pigmented counterparts. An analysis of variance and Pearson's student correlation showed that FA responded significantly with rice bran colour $(r=0.75)$ but no significant relations was found for $\mathrm{GO}$ and GABA. This result indicated that bran colour could be a quick indicator of FA content in whole grain rice. Whole grain rice rich in bioactive compounds is a good material for the development of nutraceutical products and functional food.
\end{abstract}

Keywords: Bran colour; Ferulic acid; Gamma oryzanol; Gamma aminobutyric acid (GABA); Whole grain rice

\section{INTRODUCTION}

Rice (Oryza sativa L.) is consumed as a staple carbohydrate and energy source by over one-half of the world's population with more than $90 \%$ of production in Asia. The consumption of whole grain rice may reduce the risk of many chronic diseases than pearled rice (Mira et al., 2008; $\mathrm{Liu}, 2007)$. This is mainly owed to the presence of beneficial bioactive compounds and micronutrients in their husk and bran layer (Butsat and Siriamornpun, 2010; Liu, 2007).

Whole grain rice with different colour pigments has been reported to associate with antioxidant properties. This phytochemical-rich pigments layer provides a protective effect on cell constituents against oxidative damage. Such antioxidant properties may help in preventing cancer, cardiovascular and nerve diseases (Liu, 2007; Kehrer, 1993). Moreover, coloured rice has also been used as a natural food colouring agent and aromatic agent due to its unique fragrance (Bradbury et al., 2005). The pigmented rice has gained popularity and value as functional food in local markets by offering many nutrients and health benefits through diets.

The health promoting phytochemicals of whole grain rice comprise of phenolic compounds, sterols, tocopherols, tocotrienols and amino acids. They have noteworthy antioxidant characteristics and pharmaceutical functions including the potential for preventing cancer, cardiovascular and nerve diseases, as well as functional food applications (Saikia et al., 2012; Nam et al., 2006). Ferulic acid (4-hydroxy3-methoxycinnamic acid) is a phenolic compound found covalently bound to the plant cell wall polysaccharides and localized mainly in bran fraction (Fry, 1982; Fulcher et al., 1972). Ferulic acid is present predominantly in grains in free form, soluble and insoluble conjugate form (Sosulski et al., 1982; Bunzel et al., 2001; Harukaze et al., 1998). Gamma oryzanol is primarily composed of transferulic acid esters of lipophilic phytosterols (triterpene alcohols and plant sterols) that is found in rice bran oil

\footnotetext{
${ }^{*}$ Corresponding author:

Pang Hung Yiu, Department of Basic Science and Engineering, Centre of Excellence in Borneo Ecosystem Science Research, Faculty of Agriculture and Food Sciences, Universiti Putra Malaysia, Nyabau Road, 97000 Bintulu, Sarawak, Malaysia. Tel: (6086)855432, Fax: (6086)855428, E-mail: yiuph@upm.edu.my
} 
and exhibits antioxidative activity and cholesterol-lowering effect (Miller and Engel, 2006). Gamma aminobutyric acid is a non-protein amino acid which is produced mainly by the decarboxylation of L-glutamic acid in the embryo of a seed and the production of GABA can be catalysed by the glutamate decarboxylase enzyme during the grain germination process (Bown et al., 1999). These three compounds are known as the major bioactive chemical compounds in whole grain rice.

Sarawak is endowed with ample rice varieties, including many specialty rice cultivars (Wong et al., 2009; Teo, 2010; Lee et al., 2011). These rice varieties may contain a significant amount of natural phytochemicals in their pigmented bran layers (Chee et al., 2009; Sing et al., 2011). In this study, a quantitative analysis of ferulic acid, gamma oryzanol and gamma aminobutyric acid and their relation to bran colour was investigated for fifty three rice cultivars collected from northern area of Sarawak, Malaysia. This relationship profile could provide a rapid estimation of total bioactive chemical compounds in rice cultivars and would be useful for cultivars selection in rice improvement programs.

\section{MATERIALS AND METHODS}

\section{Rice samples collection}

A total of fifty three rice cultivars (Table 1) were collected from northern divisions (Fig. 1) of Sarawak, Malaysia. The paddy samples were oven dried at $35^{\circ} \mathrm{C}$ for 2 days, dehusked manually with mortar and pestle and ground with a laboratory grinder. The powdery rice samples were sieved through a $355 \mu \mathrm{m}$ sieve and then stored in an airtight container at $4{ }^{\circ} \mathrm{C}$.

\section{Classification of bran colours}

The bran colour of whole grain rice was determined and grouped into seven colour groups according to the rice standard evaluation system (IRRI, 2002). The white colour is coded as 1 , light brown is coded as 2 , speckled brown is coded as 3 , brown is coded as 4 , red is coded as 5 , variable purple is coded as 6 and purple colour is coded as 7 for further statistical analysis.

\section{Determination of ferulic acid (FA)}

FA content of northern Sarawak rice cultivars were analysed using UV-Vis method according to the method developed by Jankovska et al. (2001) with minor modification. One gram of rice flour was weighed into a conical flask and added with $100 \mathrm{~mL}$ of $0.2 \mathrm{~mol} / \mathrm{L} \mathrm{HCl}$. The flask was kept for 30 minutes at room temperature and then heated in $85^{\circ} \mathrm{C}$ water bath for 60 minutes. The warm suspension was filtered to remove the sediment and $0.2 \mathrm{~mol} / \mathrm{L} \mathrm{NaOH}$ was added into the extracts until the $\mathrm{pH}$ reached to the value of

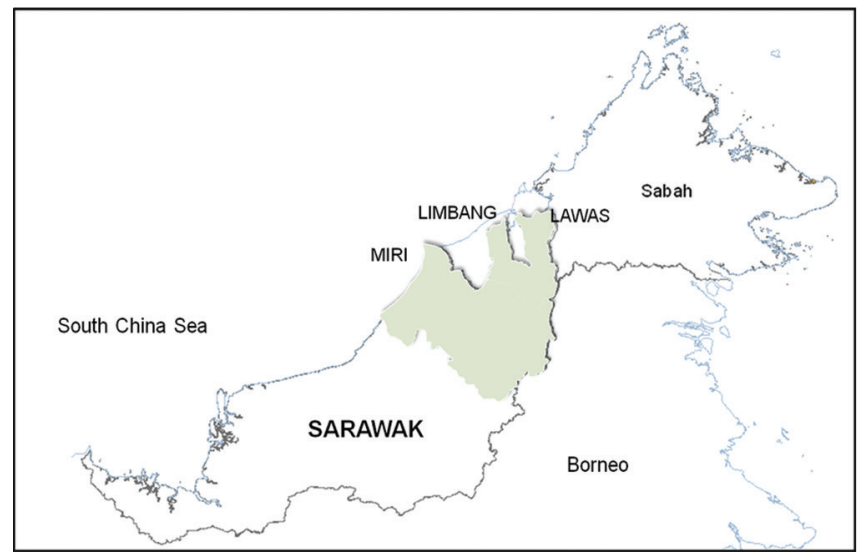

Fig 1. Sampling areas - Miri, Limbang and Lawas divisions in northern Sarawak.

12.5. The hydrolyzed extracts were kept for 60 minutes at room temperature to facilitate the saponification reaction. The reaction was ended by adding $0.2 \mathrm{~mol} / \mathrm{L} \mathrm{HCl}$ drop by drop until the $\mathrm{pH}$ value reached 10. FA was measured in UVvisible spectrometer (Scinco Co. LTD) at the wavelength of $345 \mathrm{~nm}$. FA calibration curve was constructed with $2 \mathrm{x}$ serial dilution method of pure FA standard hydrolized with $0.2 \mathrm{~mol} / \mathrm{L} \mathrm{HCl}$ and $0.2 \mathrm{~mol} / \mathrm{L} \mathrm{NaOH}$.

\section{Determination of gamma oryzanol (GO)}

GO content in rice samples was analysed using a simple spectrometry method as described by Lilitchan et al. (2008). One gram of rice flour was weighed into two centrifuge tubes respectively. Rice samples were extracted with 4 and $8 \mathrm{~mL}$ of hexane $(95 \%)$ and well mixed using vortex mixer (Velp Scientifica) for 1 minute. The organic solvent layer was separated by 2,500 rpm centrifugation (Kubota 3110) for 10 minutes. The absorbance spectra of the supernatants were measured using UV-Vis spectrometer at $314 \mathrm{~nm}$. Standard calibration curve was plotted with 2x serial dilution method of pure GO standard in hexane $(95 \%)$. Total GO content per gram of rice $(\mu \mathrm{g} / \mathrm{g})$ was calculated by solving following equation where $x_{1}$ indicates the amount $(\mu \mathrm{g})$ of $\mathrm{GO}$ in the $4 \mathrm{~mL}$ extract and $x_{2}$ indicates the amount $(\mu \mathrm{g})$ of $\mathrm{GO}$ in the $8 \mathrm{~mL}$ extracts respectively (Lilitchan et al., 2008).

$$
y=\frac{x_{1} x_{2}}{2 x_{1}-x_{2}}
$$

\section{Determination of gamma aminobutyric acid (GABA)}

GABA was analysed using High Performance Liquid Chromatography (HPLC) according to Varanyanond et al. (2005) with minor modification. One-half gram of rice flour was weighed into a centrifuge tube and added with $2 \mathrm{~mL}$ of deionized water. The sample solution was mixed with vortex mixer (Velp Scientifica) and separated by 4,500 rpm centrifugation (Allegra ${ }^{\mathrm{TM}} \mathrm{X}-22 \mathrm{R}$, Beckman Coulter) for 10 minutes. GABA was derivatized through the 
Table 1: FA, GO and GABA content $(\mu \mathrm{g} / \mathrm{g})$ among the northern Sarawak rice cultivars

\begin{tabular}{|c|c|c|c|c|c|}
\hline Cultivars/colour & Location & District & FA $(\mu g / g)$ & GO $(\mu \mathrm{g} / \mathrm{g})$ & GABA $(\mu g / g)$ \\
\hline \multicolumn{6}{|c|}{ Code 6: Variable purple } \\
\hline Hitam & Batu Niah & Miri & $1254.0^{f}$ & $776.55^{\text {hijklmno }}$ & $257.60^{g h}$ \\
\hline Hitam Keladi & Batu Niah & Miri & $1354.0^{e}$ & $1222.48^{a}$ & $56.0^{\circ}$ \\
\hline Keladi & Kpg. Menitam & Limbang & $2034.0^{\mathrm{a}}$ & $1132.32^{\mathrm{ab}}$ & $336.0^{d}$ \\
\hline Keladi & Rh. Sabang & Limbang & $1004.0^{\mathrm{jjk} / m n}$ & $583.74^{\text {opqrstuv }}$ & $81.20^{\mathrm{klmno}}$ \\
\hline Selasih Hitam & Rh. Tinggang & Miri & $1420.0^{d}$ & $509.02^{\text {rstuv }}$ & LLOQ \\
\hline Telasih/Hitam & Rh. Ekom, Sepangah & Limbang & $1651.0^{\mathrm{b}}$ & $961.48^{\text {bcdefgh }}$ & $112.0^{\mathrm{ijkl}}$ \\
\hline \multicolumn{6}{|l|}{ Code 5: Red } \\
\hline Bario Merah & Batu Niah & Miri & $1236.0^{f}$ & $411.02^{v}$ & $78.40^{\operatorname{lmno}}$ \\
\hline Merah & Kpg. Merasam Ulu & Limbang & $1516.0^{c}$ & $846.39^{\text {efghijk }}$ & $67.20^{\text {no }}$ \\
\hline Merah & Rh. Ulat, Batu Niah & Miri & $1429.0^{d}$ & $1007.28^{\text {bcdef }}$ & $442.40^{\circ}$ \\
\hline Pusu Merah & Lpg. Merasam Ulu & Limbang & $1057.0^{\text {h }}$ & $712.48^{\mathrm{jklmnopq}}$ & $72.80^{m n o}$ \\
\hline Rengut Merah & Batu Niah & Miri & $988.0^{\mathrm{jklmno}}$ & $1010.54^{\text {bcdef }}$ & LLOQ \\
\hline \multicolumn{6}{|l|}{ Code 2: Light brown } \\
\hline $3 \mathrm{~A}$ & Paya Mengeliang & Limbang & $823.0^{w x}$ & $881.79^{\text {defghij }}$ & LLOQ \\
\hline Adan & Rh. Jubang, Tanah Merah & Limbang & $973.0^{\text {mnop }}$ & $683.09^{\mathrm{klmnopqr}}$ & $89.60^{\mathrm{jkmn}}$ \\
\hline Adan & Paya Mengeliang & Limbang & $874.0^{\text {tuv }}$ & $853.20^{\text {efghijk }}$ & LLOQ \\
\hline Adan Kelabit & Bario & & $983.0^{\mathrm{klmno}}$ & $690.06^{\mathrm{jklmnopqr}}$ & $207.20^{h}$ \\
\hline Bandul & Rh. Sabang & Limbang & $791.0^{x y}$ & $576.13^{\text {pqrstuv }}$ & $81.20^{\mathrm{jklmn}}$ \\
\hline Bario & Kpg. Menitam & & $967.0^{\text {nopq }}$ & $791.92^{\text {ghijklmn }}$ & LLOQ \\
\hline Bario Panjang & Rh. Jubang, Tanah Merah & Limbang & $1147.0^{g}$ & $525.80^{\text {qrstuv }}$ & $89.60^{\mathrm{jk} \mid m n}$ \\
\hline Bario Selepin & Batu Niah & Miri & $873.0^{\text {tuv }}$ & $680.88^{\mathrm{klmnopqr}}$ & LLOQ \\
\hline Bario $(A)$ & Rh. Tinggang & Miri & $1026.0^{\text {hijklm }}$ & $830.21^{\text {tghijkl }}$ & $117.60^{\mathrm{ikk}}$ \\
\hline Beras Sederhana & Batu Niah & Miri & $1050.0^{\mathrm{hi}}$ & 642.06 Imnopqrst & $89.60^{\mathrm{jkmn}}$ \\
\hline Biris & Batu Niah & Miri & $873.0^{\text {tuv }}$ & $645.89^{\text {Imnopqrst }}$ & $100.80^{\mathrm{jkkm}}$ \\
\hline Biris & Paya Mengeliang & Limbang & $980.0^{1 \mathrm{mnop}}$ & $731.68^{\mathrm{jjk} \mid m n o p}$ & $100.80^{\mathrm{ijklm}}$ \\
\hline Biris & Kpg.Lubok Lasas & Limbang & $838.0^{\mathrm{vw}}$ & $620.09^{\text {mnopqrstu }}$ & $112.0^{\mathrm{ij}}$ \\
\hline Dari & Kpg. Belunad & Lawas & $1032.0^{\text {hijkl }}$ & $708.98^{\mathrm{jklmnopq}}$ & $252.0^{\text {efg }}$ \\
\hline Ensuluai & Rh. Tinggang & Miri & $1033.0^{\text {hijk }}$ & $802.50^{\text {ghijklmn }}$ & LLOQ \\
\hline \multicolumn{6}{|l|}{ Code 2: Light brown } \\
\hline Gupung & Rh. Ekom, Sepangah & Limbang & $1060.0^{\mathrm{h}}$ & $1078.51^{\mathrm{abc}}$ & $128.80^{i}$ \\
\hline Jepun & Batu Niah & Miri & $907.0^{\text {rstu }}$ & $584.74^{\text {oparstuv }}$ & LLOQ \\
\hline Kubok & Rh. Ekom, Sepangah & Limbang & $897.0^{\text {stu }}$ & $745.89^{\mathrm{jk} k \mathrm{mnop}}$ & $78.40^{1 \mathrm{mno}}$ \\
\hline Mayang & Rh. Sabang & Limbang & $1002.0^{\mathrm{jjk} / m n}$ & $977.44^{\text {bcdefg }}$ & $78.40^{1 \mathrm{mno}}$ \\
\hline Meet & Rh. Sabang & Limbang & $790.0^{x y}$ & $689.55^{\mathrm{jklmnopqr}}$ & $78.40^{1 \mathrm{mno}}$ \\
\hline Minyak & Paya Mengeliang & Limbang & $714.0^{z}$ & $646.75^{\text {Imnopqrst }}$ & $67.20^{\mathrm{no}}$ \\
\hline Pandan & Kpg. Menitam & Limbang & $862.0^{\mathrm{uvw}}$ & $710.18^{\mathrm{jklmnopq}}$ & $285.60^{e}$ \\
\hline Pandan & Batu Niah & Miri & $979.0^{\text {mnop }}$ & 674.23 & LLOQ \\
\hline Pasir & Kpg. Menitam & Limbang & $930.0^{\text {pqrs }}$ & $479.19^{\text {tuv }}$ & $308.0^{d}$ \\
\hline Pulut Emas & Kpg. Merasam Ulu & Limbang & $962.0^{\text {nopq }}$ & $924.19^{\text {cdefghi }}$ & $84.0^{\mathrm{klmno}}$ \\
\hline Pusu & Kpg. Lubok Lasas & Limbang & $930.0^{\text {pqrs }}$ & $1042.80^{\mathrm{bcd}}$ & LLOQ \\
\hline Pusu & Rh. Sabang & Limbang & $937.0^{\text {opqrs }}$ & $709.92^{\mathrm{jklmnopq}}$ & $100.80^{\mathrm{ikkm}}$ \\
\hline Rengut Putih & Batu Niah & Miri & $907.0^{\text {rstu }}$ & $770.76^{\text {hijklmnop }}$ & $70.0^{\mathrm{mno}}$ \\
\hline Roti & Batu Niah & Miri & $988.0^{\mathrm{jklmno}}$ & $603.85^{\text {nopqrstu }}$ & LLOQ \\
\hline Roti & Kpg. Belunad & Lawas & $907.0^{\text {rstu }}$ & $806.56^{\mathrm{ghijklm}}$ & LLOQ \\
\hline Salleh & Batu Niah & Miri & $989.0^{\mathrm{jkmn}}$ & $801.38^{\text {ghjiklmn }}$ & $229.60^{g h}$ \\
\hline Sarau & Batu Niah & Miri & $921.0^{\text {qrst }}$ & $436.20^{\mathrm{uv}}$ & LLOQ \\
\hline Segerit & Batu Niah & Miri & $1036.0^{\mathrm{hijk}}$ & $804.19^{\text {ghijklm }}$ & $800.80^{b}$ \\
\hline Seluai & Batu Niah & Miri & $1051.0^{\mathrm{hi}}$ & $742.62^{\mathrm{ijk} \mid m n o p}$ & LLOQ \\
\hline Semanyok Merah & Batu Niah & Miri & $771.0^{y}$ & $645.27^{\text {Imnopqrst }}$ & $95.20^{\mathrm{jklmn}}$ \\
\hline Sentra & Paya Mengeliang & Limbang & $956.0^{\text {nopqr }}$ & $766.45^{\mathrm{ijk} \mid m n o p}$ & $92.40^{\mathrm{jkmn}}$ \\
\hline Seratus & Kpg. Menitam & Limbang & $990.0^{\mathrm{jkmn}}$ & $1219.24^{a}$ & $1176.0^{\mathrm{a}}$ \\
\hline Siam & Batu Niah & Miri & $997.0^{\mathrm{jkmn}}$ & $483.61^{\text {stuv }}$ & $100.80^{\mathrm{ikkm}}$ \\
\hline Thomas & Kpg. Menitam & Limbang & $922.0^{\text {qrst }}$ & $777.38^{\text {hijklmno }}$ & $291.20^{\text {ef }}$ \\
\hline Tiga $A$ & Batu Niah & Miri & $1040.0^{\text {hij }}$ & $1030.78^{\text {bcde }}$ & $263.20^{\text {fgh }}$ \\
\hline Tit & Batu Niah & Miri & $1140.0^{g}$ & $449.94^{\mathrm{uv}}$ & LLOQ \\
\hline Tit & Kpg. Belunad & Lawas & $1023.0^{\mathrm{hijk} k \mathrm{~m}}$ & 729.39jiklmnop & LLOQ \\
\hline
\end{tabular}


reaction of adding $1 \mathrm{~mL}$ of supernatant with $200 \mu \mathrm{L} 0.4 \mathrm{M}$ $\mathrm{NAHCO}_{3}$ and $200 \mu \mathrm{L}$ of $6 \mathrm{mM}$ DABSYL-Cl acetonitrile solution. Then the sample was heated in $70^{\circ} \mathrm{C}$ water bath for 20 minutes to complete the derivatization reaction. The warm suspension was filtered through $0.45 \mu \mathrm{m}$ nylon filter membrane before injecting into HPLC system. GABA content was quantified using HPLC Isocratic System (Waters). Ten microliters of filtrate was injected into a reversed phase C18 column and determined with UV detector at $436 \mathrm{~nm}$. The column temperature was maintained at $30{ }^{\circ} \mathrm{C}$. The composition of the optimized mobile phase A was $25 \mathrm{mM}$ potassium dihydrogen phosphate $(35 \%)$ at $\mathrm{pH} 6.8$, mobile phase $\mathrm{B}$ was acetonitrile $(45 \%)$ and mobile phase $\mathrm{C}$ was methanol $(20 \%)$. The flow rate was set at $0.5 \mathrm{~mL} / \mathrm{min}$. The GABA content was calculated with an external standard calibration curve which was plotted by $2 \mathrm{x}$ serial dilution of GABA standard in DABSYL-Cl acetonitrile solution.

\section{Statistical analysis}

The data obtained from the analysis were then analysed using Statistical Analysis Software (SAS) version 9.2. Analysis of variance (ANOVA) was used to analyse the variations of $F A, G O$ and GABA content among the rice cultivars and bran colours. Duncan's New Multiple Range Test (DNMRT) was used for mean comparisons. Pearson's student correlation was performed to test on the relations between bran colour and bioactive chemical compounds.

\section{RESULTS AND DISCUSSION}

\section{Rice bran colour}

Majority of the rice cultivars showed rice bran in light brown colour (79.24\%) followed by variable purple colour $(11.32 \%)$ and red colour $(9.43 \%)$. These showed that dark coloured rice is less commonly cropped by local farmers in northern Sarawak. The dark coloured rice could be less appealing in appearance than light coloured rice for the consumers in northern Sarawak region. The distribution of the rice cultivars with different rice bran colour were shown in Fig. 2.

\section{Ferulic acid content}

FA rarely occurs in free form in plants. It is usually found as ester covalently conjugated with cell wall polysaccharide, proteins, lignin and other insoluble carbohydrate biopolymers (Barnerousse et al., 2008). FA was extracted in this study by chemical hydrolysis which breaks the ester linkages with polysaccharides and lignin and followed by saponification with diluted sodium hydroxide solutions. The amount of FA was measured as sodium ferulate under UV-Vis light (Mathew and Abraham, 2004).

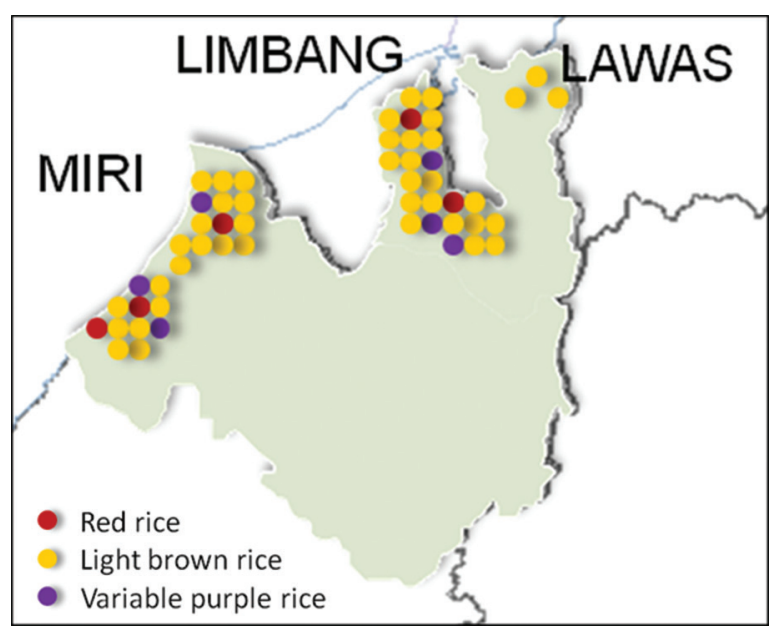

Fig 2. The distribution of rice cultivars collected according to divisions.

Table 2: The mean of the FA, GO and GABA content grouped according to sampling districts

\begin{tabular}{lccccccc} 
Districts & N & \multicolumn{2}{c}{ FA $(\mu \mathrm{g} / \mathrm{g})$} & \multicolumn{2}{c}{ GO $(\mu \mathrm{g} / \mathrm{g})$} & \multicolumn{2}{c}{ GABA $(\mu \mathrm{g} / \mathrm{g})$} \\
\cline { 3 - 7 } & & Mean & S.D. & Mean & S.D. & Mean & S.D. \\
\hline Lawas & 3 & $13.42 \mathrm{a}$ & 23.25 & $680.77 \mathrm{a}$ & 67.35 & $8.33 \mathrm{a}$ & 14.43 \\
Miri & 25 & $34.25 \mathrm{a}$ & 171.26 & $735.32 \mathrm{a}$ & 202.86 & $28.80 \mathrm{a}$ & 34.30 \\
Limbang & 25 & $58.71 \mathrm{a}$ & 293.53 & $789.73 \mathrm{a}$ & 191.39 & $42.28 \mathrm{a}$ & 35.04 \\
\hline
\end{tabular}

Means with different letters within the same column are significantly different (DNMRT, $P<0.05)$. S.D. indicates standard deviation of the respective population

The FA content in fifty three northern Sarawak rice cultivars was significantly different between cultivar and ranged from 714.0 to $2034.0 \mu \mathrm{g} / \mathrm{g}$. The FA content in the rice collection is relatively high compared to Japanese brown rice $(0.032$ to $1.96 \mu \mathrm{g} / \mathrm{g}$ ), Chinese brown rice (350.0 to $400.0 \mu \mathrm{g} / \mathrm{g}$ ) and Australian brown rice (255 to $362 \mu \mathrm{g} / \mathrm{g}$ ) (Tian et al., 2004; Zhou et al., 2003). The rice cultivars showed the mean of $1034.2 \mu \mathrm{g} \mathrm{FA} / \mathrm{g}$ samples, with exceptionally high FA content detected in cultivar Keladi from Kpg. Menitam, Limbang $(2034.0 \mu \mathrm{g} F A / g)$. The FA content in these rice cultivars was not significantly different between cultivation locations (Table 2) but significantly different between bran colour (Table 3). FA content was found to be higher in whole grain rice with rice bran in variable purple colour, followed by red colour and light brown colour. This trend often reflected in antioxidant activity of whole grain rice, where darker pigmented rice possessed higher amount of phenolics and antioxidative activities (Shen et al., 2009; Goffman and Bergman, 2002; Nam et al., 2006). These suggest that FA is the major phytochemical responsible for the antioxidant activity of dark coloured rice.

\section{Gamma oryzanol content}

GO contains an alcohol group (-OH) in its ferulate portion, which makes it relatively high polarity and likely to be soluble in both polar and non polar solvents (Xu and Godber, 2000). The amount of GO in the rice collection 
Table 3: The mean of the FA, GO and GABA content grouped according to rice bran colour

\begin{tabular}{|c|c|c|c|c|c|c|c|}
\hline \multirow[t]{2}{*}{ Bran colour } & \multirow[t]{2}{*}{$\mathbf{N}$} & \multicolumn{2}{|c|}{ FA $(\mu g / g)$} & \multicolumn{2}{|c|}{ GO $(\mu \mathrm{g} / \mathrm{g})$} & \multicolumn{2}{|c|}{ GABA $(\mu \mathrm{g} / \mathrm{g})$} \\
\hline & & Mean & S.D. & Mean & S.D. & Mean & S.D. \\
\hline$-1 y \mid$ & 42 & 949.31 & 94.27 & 737 & 168.84 & $30.12 a$ & 35.45 \\
\hline \}ed & 5 & $1245.20 \mathrm{~b}$ & 228.46 & $797.54 a$ & 249.19 & $66.20 a$ & 13.05 \\
\hline lariable & 6 & $1452.83 c$ & 354.6 & 864.27 & 290.60 & $34.33 a$ & 29.86 \\
\hline
\end{tabular}

Means with different letters within the same column are significantly different (DNMRT, $P<0.05)$. S.D. indicates standard deviation of the respective population

was significantly different between cultivar and ranged from 411.02 to $1222.48 \mu \mathrm{g} / \mathrm{g}$, with the mean of $757.9 \mu \mathrm{g} / \mathrm{g}$. GO content in present work was within a narrow range while compared to southern Sarawak rice cultivars (370 to $1290 \mu \mathrm{g} / \mathrm{g}$ ) as reported by Chee et al. (2009). The highest content of GO was recorded in Hitam Keladi from Batu Niah, Miri with $1222.48 \mu \mathrm{g}$ GO/g rice. The GO content in these rice cultivars was not significantly different between cultivation locations (Table 2) and bran colour (Table 3).

\section{Gamma aminobutyric acid content}

GABA content in the rice collection was significantly different between rice cultivars with the range from nondetectable level to $1176.0 \mu \mathrm{g}$ GABA/g rice. Majority of the rice cultivars showed GABA content below $500 \mu \mathrm{g} / \mathrm{g}$ while $30 \%$ of the rice cultivars showed non-detectable level of GABA. The GABA content in these rice cultivars was not significantly different between cultivation locations (Table 2) and bran colour (Table 3). Most of the cultivars in present study showed relatively higher GABA content than Thailand brown rice (30.80 to $58.80 \mu \mathrm{g} / \mathrm{g}$ ) (Karladee and Suriyong, 2012). Exceptionally high GABA content was recorded in Segerit $(800.80 \mu \mathrm{g} / \mathrm{g})$ and Seratus $(1176.0 \mu \mathrm{g} / \mathrm{g})$, which could be associated with their high amylose content. Varanyanond revealed that GABA content varies with amylose content due to the embryo size of the rice grains. High amylose rice provides larger germ portion and higher GABA content which accumulates only in the germ of a grain (Varanyanond et al., 2005).

\section{Phytochemicals profile and bran colour}

Although $70 \%$ of the rice collection showed low level of $\mathrm{FA}, \mathrm{GO}$ and GABA, the remaining rice cultivars showed good profiles of bioactive chemical compounds, either rich in FA, GO, GABA or all of the bioactive compounds measured. These rice cultivars mainly consisted of dark pigmented rice with bran in red or variable purple colour, which are associated with high FA and GO content. There are few rice cultivars with bran in light brown colour showing high GABA content. Rice cultivars with notable high content in these bioactive compounds includes Seratus from Kpg. Menitam, Limbang (1176.0 $\mu \mathrm{g}$ GABA/g; $1219.24 \mu \mathrm{g} \mathrm{GO/g;} 990.0 \mu \mathrm{g} \mathrm{FA} / \mathrm{g}$ ), Segerit (800.80 $\mu \mathrm{g} \mathrm{GABA/g,} \mathrm{804.19} \mu \mathrm{g} \mathrm{GO} / \mathrm{g}$ and $1036.0 \mu \mathrm{g}$
Table 4: Correlation matrix between bran colour and the level of bioactive compounds

\begin{tabular}{lcccc}
\hline & GO & FA & GABA & Colour \\
\hline GO & & & & \\
Pearson correlation & 1 & $0.328^{*}$ & -0.029 & 0.214 \\
Sig. (2-tailed) & & 0.016 & 0.838 & 0.124 \\
N & 53 & 53 & 53 & 53 \\
FA & & & & \\
Pearson correlation & $0.328^{*}$ & 1 & 0.000 & $0.748^{\star *}$ \\
Sig. (2-tailed) & 0.016 & & 0.999 & 0.000 \\
N & 53 & 53 & 53 & 53 \\
GABA & & & & \\
Pearson correlation & -0.029 & 0.000 & 1 & 0.185 \\
Sig. (2-tailed) & 0.838 & 0.999 & & 0.184 \\
N & 53 & 53 & 53 & 53 \\
Colour & & & & \\
Pearson correlation & 0.214 & $0.748^{* *}$ & 0.185 & 1 \\
Sig. (2-tailed) & 0.124 & 0.000 & 0.184 & \\
N & 53 & 53 & 53 & 53 \\
\hline
\end{tabular}

* Indicates correlation is significant at the 0.05 level (2-tailed). ${ }^{* *}$ Indicates correlation is significant at the 0.01 level (2-tailed)

FA/g), Merah from Rh. Ulat, Batu Niah (442.40 $\mu \mathrm{g}$ $\mathrm{GABA} / \mathrm{g}, 1007.28 \mu \mathrm{g} \mathrm{GO} / \mathrm{g}$ and $1429.0 \mu \mathrm{g} \mathrm{FA} / \mathrm{g})$ and Keladi from Menitam (336.0 $\mu \mathrm{g}$ GABA/g, $1132.32 \mu \mathrm{g}$ $\mathrm{GO} / \mathrm{g}$ and $2034.0 \mu \mathrm{g} \mathrm{FA} / \mathrm{g})$.

Coloured rice varieties, same as other coloured plants such as red grape, tomato and blueberry are known to be strong in antioxidative activities (Kaneda et al., 2006). In this study, there are strong relationship between bran colour and FA content but not in GO and GABA content (Table 4). These were in congruence with previous studies reported on higher levels of total phenolic and antioxidant capacity in pigmented genotypes (Sompong et al., 2011; Shen et al., 2009; Mira et al., 2008; Kaneda et al., 2006; Nam et al., 2006; Goffman and Bergman, 2002). No relationship was found between rice bran colour and GO content although correlation was found between GO and FA. This could be due to difference in their chemistry including pigmentation and solubility behaviours. GABA, present abundantly in embryo of rice grains is also not associated with rice bran colour, possibly due to low GABA in bran layer.

\section{CONCLUSION}

Present study revealed that bioactive compounds in whole grain rice had different association with bran colour. The level of FA was significantly correlated with rice bran colour, but no correlation was found for GO and GABA. The level of FA followed the trend of variable purple $>$ red $>$ light brown, which are commonly associated with antioxidant activity. Therefore, bran colour could serve as an indicator of FA content in whole grain rice. This information could assist rice producers or food technologists in rice cultivar 
selection for nutraceutical food developments and also targeted compounds extraction.

\section{ACKNOWLEDGEMENT}

The authors would like to acknowledge Department of Agriculture (DOA) Sarawak in sample collection, Associate Professor Dr. Rajan Amartalingam for his invaluable advises in this project, and also Wong Ting Sheau and Wong Ling Ling on their contribution in the analytical works. This research was financially supported by Universiti Putra Malaysia (RUGS 05-01-12-1654RU) and Ministry of Education Malaysia (FRGS 01-01-13-1246FR).

\section{Author Contributions}

S. X. S. made the major contribution in data collection and writing of the manuscript. All other authors made equal contributions, edited and approved the manuscript.

\section{REFERENCES}

Barnerousse, H., O. Roiseux, C. Robert, M. Paquot, C. Deroanne and C. Blecker. 2008. Analytical methodologies for quantification of ferulic acid and its oligomers. J. Sci. Food Agri. 88: 1494-1511.

Bown, A. W., M. D. McLean and B. J. Shelp. 1999. Metabolism and functions of gamma-aminobutyric acid. Trends Plant Sci. 4: 446452.

Bradbury, L. M., T. L. Fitzgerald, R. J. Henry, Q. Jin and D. L. Waters. 2005. The gene for fragrance in rice. Plant Biotechnol. J. 3: 363370.

Bunzel, M., J. Ralph, J. M. Martia, R. D. Hatfield, H. Steinhard. 2001. Diferulates as structural components in soluble and insoluble cereal dietary fibre. J. Sci. Food Agri. 81: 653-660.

Butsat, S. and S. Siriamornpun. 2010. Antioxidant capacities and phenolic compounds of the husk, bran and endosperm of Thai rice. Food Chem. 119: 606-613.

Chee, Y. M., S. Y. Wong, P. H. Yiu, S. C. Wong and A. Rajan. 2009. Quality characteristics and nutritional potential of selected rice cultivars from southern Sarawak. th $^{\text {th }}$ TWAS Young Scientist Conference 2009 Programme and Abstracts. p. 92.

Fry, S. C. 1982. Phenolic components of the primary cell wall. J. Biochem. 203: 493-504.

Fulcher, R. G., T. P. O'Brien, J. W. Lee. 1972. Observations on the aleurone layer. I. Conventional and fluorescence microscopy of the cell wall with emphasis on phenol-carbohydrate complexes in wheat. Aust. J. Biol. Sci. 25: 23-34.

Goffman, F. D. and C. Bergman. 2002. Total phenolics and antiradical efficiency of rice bran extracts. Proceedings of $29^{\text {th }}$ Rice Technical Workshop Group Meet, Little Rock, AR.

Harukaze, A., M. Murata and S. Homma. 1998. Analyses of free and bound phenolics in rice. J. Food Sci. Tech. Res. 5: 74-79.

International Rice Research Institute (IRRI) 2002. Standard Evaluation System for Rice. Available from: www.knowledgebank.irri.org/ images/ docs/ricestandardevaluationsystem.pdf. [Last accessed on 2015 May 23].

Jankovska, P., J. Copikova and A. Sinitsya. 2001. The determination of ferulic acid in sugar beet pulp. Czech J. Food Sci. 19: 143147.
Kaneda, I., F. Kubo and H. Sakurai. 2006. Antioxidative compounds in the extracts of black rice brans. J. Health Sci. 52: 495-511.

Karladee, D. and S. Suriyong. 2012. $\gamma$-aminobutyric acid (GABA) content in different varieties of brown rice during germination. Sci. Asia. 38: 13-17.

Kehrer, J. P. 1993. Free radicals as mediators of tissue injury and disease. Crit. Rev. Toxicol. 23: 21-48.

Lee, H. H., P. N. Neoh, S. T. Bong, S. C. Wong, P. H. Yiu and A. Rajan. 2011. Genotyping of Sarawak rice cultivars using microsatellite markers. Pertanika J. Trop. Agri. Sci. 34: 123-136.

Lilitchan, S., C. Tangprawat, K. Aryusuk, S. Krisnangkura, S. Chokmoh and K. Krisnangkura. 2008. Partial extraction method for the rapid analysis of total lipids and $y$-oryzanol contents in rice bran. Food Chem. 106: 752-759.

Liu, R. H. 2007. Whole grain phytochemicals and health. J. Cereal Sci. 46: 207-219.

Mathew, S. and T. Abraham. 2004. Ferulic acid: An antioxidant found naturally in plant cell walls and feruloyl esterases involved in its release and their application. Crit. Rev. Biotechnol. 24: 59-83.

Miller, A. and K. H. Engel. 2006. Content of $\gamma$-oryzanol and composition of steryl ferulates in brown rice (Oryza sativa L.) of European origin. J. Agri. Food Chem. 54: 8127-8133.

Mira, N. V., I. L. Massaretto, C. S. Pascual and U. M. Marquez. 2008. Comparative study of phenolic compounds in different Brazilian rice (Oryza sativa L.) genotypes. J. Food Compost. Anal. 22: 405-409.

Nam, S. H., S. P. Choi, M. Y. Kang, H. J. Koh, N. Kozukue and M. Fredman. 2006. Antioxidative activities of bran extracts from twenty one pigmented rice cultivars. Food Chem. 94: 613-620.

Saikia, S., H. Dutta, D. Saikia, C. L. Mahanta. 2012. Quality characterization and estimation of phytochemicals content and antioxidant capacity of aromatic pigmented and non-pigmented rice varieties. Food Res. Int. 46: 334-340.

Shen, Y., L. Jin, P. Xiao, Y. Lu and J. Bao. 2009. Total phenolics, flavonoids, antioxidant capacity in rice grain and their relations to grain colour, size and weight. J. Cereal Sci. 49: 106-111.

Sing, S. X., T. S. Wong, L. L. Wong, H. H. Lee and P. H. Yiu. 2011. Health promoting phytochemicals in Sarawak Pigmented Rice. Proceedings of Sarawak Rice Conference 2011. p. 27.

Sompong, R., S. Siebenhandl-Ehn, G. Linsberger-Martin and E. Berghofer. 2011. Physicochemical and antioxidative properties of red and black rice varieties from Thailand, China and Sri Lanka. Food Chem. 124: 132-140.

Sosulski, F., K. Krygier and L. Hogge. 1982. Free, esterified, and insoluble-bound phenolic acids. 3. Composition of phenolic acids in cereal and potato flours. J. Agri. Food Chem. 30: 337-340.

Teo, G. K. (2010). Rice Biodiversity, Semongok, Sarawak, Malaysia.

Tian, S., K. Nakamura and H. Kayahara. 2004. Analysis of phenolic compounds in white rice, brown rice, and germinated brown rice. J. Agri. Food Chem. 52: 4808-4813.

Varanyanond, W., P. Tungtrakul, V. Surojanametakul, L. Watanasiritham and L. X. Wang. 2005. Effects of water soaking on gamma-aminobutyric acid (GABA) in germ of different Thai rice varieties. J. Nat. Sci. 39: 411-415.

Wong, S. C., P. H. Yiu, S. T. Bong, H. H. Lee, P. N. Neoh and A. Rajan. 2009. Analysis of Sarawak Bario rice diversity using microsatellite markers. Am. J. Agri. Biol. Sci. 4: 298-304.

Xu, Z. and J. S. Godber. 2000. Comparison of supercritical fluid and solvent extraction methods in extracting $\gamma$-oryzanol from rice bran. J. Am. Oil Chem. Soc. 77: 547-551.

Zhou, Z., K. Robards, S. Helliwell and C. Blanchard. 2003. The distribution of phenolic acids in rice. J. Food Chem. 87: 401-406. 